\title{
O COMBATE DA CASTIDADE: AUTONOMIA E EXERCÍCIO DA SEXUALIDADE ENTRE HOMENS EVANGÉLICOS COM PRÁTICAS HOMOSSEXUAIS 1
}

Resumo: Este artigo problematiza a elaboração de identidades pessoais em face das complexas constelações culturais contemporâneas. Considerando que existem múltiplos discursos relativos à homossexualidade, reflete-se sobre a produção de identidades sexuais de sujeitos com pertença religiosa. Parte-se do suposto de que processos de construção de si estão imbricados a questões de gênero, inserção social e clivagens como religião e orientação sexual. Primeiramente, reflete-se sobre as possíveis correlações entre percursos afetivo-sexuais e trajetórias religiosas. A partir disso, são analisados discursos sobre a experiência de buscar "cura" na esfera da sexualidade, focalizando narrativas sobre a participação em rituais de libertação e aconselhamentos pastorais. O material etnográfico consiste em entrevistas realizadas entre os anos de 2001 e 2005, entre sujeitos de distintas denominações pentecostais no universo evangélico, residentes em regiões da Baixada Fluminense e Zona Norte do Rio de Janeiro.

Palavras-chave: Religião, Sexualidade, Psicologização, Pentecostalismo e Homossexualidade.

\begin{abstract}
The article deals with personal identities elaboration in face of complex contemporary cultural backgrounds. Considering that there are multiple speeches related to homosexuality, thoughts have been made about subjects from religious belonging sexual identities production. It starts from the point that self building processes are related with gender, social insertion issues and cut offs such as religion and sexual orientation. Primarily, it deals with possible correlations between sexual/affective pursuits and religious trajectories. From that, speeches are analyzed about the experience of searching "cure" in sexual sphere, focusing on narratives about participation in releasing rituals and pastoral counseling. The ethnographic material consists in interviews during the years of 2001 and 2005, among subjects from distinct pentecostal denominations, living in Baixada Fluminense and North Zone of Rio de Janeiro.
\end{abstract}

Keywords: Religion, Homosexuality, Psychology, Pentecostalism. 